\title{
Technology of Underway Clothing Building with Using of Alumina Industrial Waste
}

Igor I. Shepelev*a, Anatoly M. Zhyzhaev ${ }^{\mathrm{b}}$ and Nikolay N. Bochkov

${ }^{a}$ Research Institution ECO-Engineering LLC 1 Str., XII Kvartal, Yuzhnaya Promzona, Achinsk, 662150, Russia ${ }^{b}$ Institute of Chemistry and Chemical Technology SB RAS 24/50 Akademgorodok, Krasnoyarsk, 660036, Russia “《DPMK of Achinsk》, Ltd》 12 Str., V Kvartal, Yuzhnaya Promzona, Achinsk, 662153, Russia

Received 23.04.2015, received in revised form 12.05.2015, accepted 16.10.2015

The searching of composition gradation for complex mineral binder on base of alumina industrial waste was carried out. The strength characteristics of road mixtures and structure of binder mineral components after mixture hydration processes were investigated. Optimal road constructive compositions were determined which have maximal effective properties. Technology of subgrade building using nepheline slime, gypsum-anhydrite waste products and dust from gas treatment systems was proposed and tested in practice. Binder compositions proposed give some possibility of alumina industrial waste utilization and give raised to pavement strength factor and frost resistance increasing.

Keywords: nepheline slime, gypsum-anhydrite waste, compression strength, dust from industrial gas cleaning collector, underway clothing, complex binder.

DOI: 10.17516/1999-494X-2015-8-8-1070-1082.

(C) Siberian Federal University. All rights reserved

* Corresponding author E-mail address: ekoing@mail.ru 


\title{
Технология строительства дорожных одежд с использованием отходов глиноземного производства
}

\author{
И.И. Шепелев ${ }^{\text {a }, ~ А . М . ~ Ж и ж а е в ~}{ }^{\text {, }}$ Н.Н. Бочков ${ }^{\text {в }}$ \\ ${ }^{a}$ Научно-исследовательская организачия «ЭКО-Инжиниринг» \\ Россия, 662150, Ачинск, Южная промзона, квартал XII, стр. 1 \\ ${ }^{6}$ Институт химии и химической технологии СО РАН \\ Россия, 660036, Красноярск, Академгородок, 50, стр. 24 \\ ${ }^{\circ}$ Дорожно-передвижная механизированная колонна «Ачинская» \\ Россия, 662153, Ачинск, Южная промзона, квартал V, стр. 12
}

Проведены исследования по подбору составов комплексного неорганического вяжущего на основе производственных отходов глиноземного производства. Изучены прочностные характеристики дорожных смесей и структура вяжущих минеральных продуктов. Определены наиболее оптимальные и эффективные составы дорожных смесей. Разработана и испытана технология строительства основания дорожных одежд на основе использования нефелинового шлама, гипсоангидритовых отходов и пыли газоочистных сооружений, обеспечивающая, помимо частичной утилизации отходов глиноземного производства, увеличение прочностных свойств и морозостойкость дорожных смесей.

Ключевые слова: нефелиновый шлам, гипсоангидритовые отходы, предел прочности, пыль газоочистных сооружений, дорожные одежды, комплексное вяжущее.

\section{Введение}

Производство практически всех цветных металлов сопряжено с образованием большого количества отходов различной степени токсичности. Все это создает напряженность на территориях, где работают эти предприятия. Имеется опыт использования отходов металлургической промышленности $[1,2]$. Общий объем утилизации шлаков черной металлургии составляет около 60 \%, несколько лучше перерабатываются доменные шлаки - 80 \%. С высокой эффективностью (на 30-50 \%) шлаки могут быть применены в качестве наполнителя для бетона вместо щебня, полученного из природного сырья [3]. В настоящее время в России слабо внедряются результаты прежних научных разработок в части использования отходов производства в строительстве и производстве строительных материалов. При строительстве автомобильных дорог в РФ и за рубежом в последние годы находят все более широкое применение основания из грунтов и каменных материалов, укрепленных различными вяжущими $[1,4,5]$. Это связано с тем, что при высокой интенсивности движения, которая в настоящее время имеет место, неукрепленные основания уже не могут обеспечить сохранения в течение длительного времени требуемой ровности покрытия и несущей способности дорожной одежды в целом. Основания из материалов, укрепленных вяжущим, не только прочны и долговечны, но и экономичны, поскольку открывают возможность использовать местные некондиционные каменные материалы и промышленные отходы взамен дорогостоящего цемента. На основании вышеизложенного можно считать, что ОАО «РУСАЛ Ачинск», имея в своей основе комплексную технологию переработки нефелиновой руды, обладает существенным резервом создания малоотходной технологии 
с вторичной переработкой нефелинового шлама, обладающего ярко выраженными вяжущими свойствами для использования его в строительных и дорожно-строительных технологиях [6-9].

Целью настоящих исследований является разработка и опытно-промышленная апробация технологии строительства основания дорожных одежд с использованием отходов глиноземного производства.

\section{Методы исследований}

Методика исследований предусматривала изучение свойств твердеющих составов дорожных смесей, их прочностных характеристик на основе новообразований в процессе гидратации. Рентгенофазовый анализ (РФА) состава компонентов и получаемых дорожных смесей проводили на рентгеновском дифрактометре ДРОН-3 с использованием $C u_{K \alpha}$-излучения ( $\lambda=1,544$ нм), шаг сканирования 0,02 град, время накопления в точке $1 \mathrm{c}$. Микроструктуру и морфогеометрию минеральных продуктов исследовали на сканирующем электронном микроскопе $T M-3000$ (Hitachi, Япония) в обратно отраженных электронах (ускоряющее напряжение 15 кэВ). Микрорентгеноспектральный анализ выполняли на встроенном энергодисперсионном спектрометре (Bruker) с помощью системы микроанализа Quantax-70. Порошковые минеральные образцы для электронной микроскопии пропитывали эпоксидной смолой Epofix. После полимеризации полученные шашки шлифовали на шлифовально-полировальном станке TegraPol 15 (бумага на основе $\mathrm{SiC}, \mathrm{P} 200-\mathrm{P} 2000)$ и полировали вручную на резиновом диске с использованием полировальных суспензий $3 M$ на основе корунда. Определение прочности образцов проводилось в возрасте 7, 14, 28 сут на пресс-машине УМЭ-10ТМ.

\section{Результаты исследований}

Для укрепления основания дорожных одежд и повышения эксплуатационных свойств дорожного покрытия предлагается использовать комплексное неорганическое вяжущее, полученное из нефелинового шлама, активированного гипсоангидритовыми отходами. В качестве исходных материалов при разработке технологии получения комплексного вяжущего и приготовления дорожных одежд исследовали нефелиновый шлам (НШ) и гипсосодержащие отходы и пыль газоочистных сооружений глиноземного производства ОАО «РУСАЛ Ачинск». Нефелиновый шлам ОАО «РУСАЛ Ачинск» является «хвостовым» продуктом переработки КияШалтырских нефелинов совместно с известняком Мазульского карьера, получаемым после извлечения глинозема и содопродуктов. Известно [9], что из общего количества нефелинового шлама текущего производства лишь около 300 тыс. т используется комбинатом для выпуска портландцемента, остальной шлам - свыше 6 млн т в год - поступает в шламохранилище. На картах № 1 и 2 шламохранилища АГК накопилось гидратированного нефелинового шлама более 100 млн т.

По данным РФА, нефелиновый шлам представлен в основном ларнитом $\left(\beta-\mathrm{Ca}_{2} \mathrm{SiO}_{4}\right.$, $d=2,78 ; 2,74 ; 2,19 \AA, J C P D S, 29-371)$ с небольшой примесью ранкинита $\left(\mathrm{Ca}_{3} \mathrm{Si}_{2} \mathrm{O}_{7}, d=5,48 ; 3,82\right.$; $3,04 \AA, J C P D S, 23-124)$ (рис. 1). Отмечено также присутствие слабых линий соды (термонатрит, $\mathrm{Na}_{2} \mathrm{CO}_{3} \times \mathrm{H}_{2} \mathrm{O}, d=5,29 ; 4,12 ; 2,44 \AA, J C P D S, 8-448$ ) и карбонатов кальция (кальцит, $\mathrm{CaCO}_{3}, d=3,04$; $3,86 ; 1,912 \AA, J C P D S, 47-1743)$. Возможно наличие диопсида $\left(\mathrm{CaMg}\left(\mathrm{SiO}_{3}\right)_{2}, d=3,34 ; 2,54 ; 2,215 \AA\right.$, 
$J C P D S, 19-239)$, но его основные пики перекрываются линиями других фаз. Химический состав нефелинового отвального шлама дан в табл. 1.

Минеральный состав размещаемого на шламовом поле нефелинового шлама представлен в основном двухкальциевым силикатом (более 80 \%), в качестве следов до 5 \% в отвальном шламе присутствуют: алюминаты натрия $\mathrm{Na}_{2} \mathrm{O} \times \mathrm{Al}_{2} \mathrm{O}_{3}$, кальциймагниевые силикаты $\mathrm{CaO} \times \mathrm{MgO} \times \mathrm{SiO}_{2}$, натрокальциевые силикаты $\mathrm{Na}_{2} \mathrm{O} \times \mathrm{CaO} \times \mathrm{SiO}_{2}$, гидрогранаты кальция $3 \mathrm{CaO} \times \mathrm{Al}_{2} \mathrm{O}_{3} \times \mathrm{SiO}_{2} \times(6-\mathrm{x})$ $\mathrm{H}_{2} \mathrm{O}$, кальциевые алюминаты $\mathrm{CaO} \times \mathrm{Al}_{2} \mathrm{O}_{3}$ [5], что согласуется с нашими данными.

Таблица 1. Химический состав нефелинового шлама

\begin{tabular}{|c|c|}
\hline Компонент & Содержание, \% масс. \\
\hline $\mathrm{SiO}_{2}$ & 29,9 \\
\hline $\mathrm{CaO}$ & 54,7 \\
\hline $\mathrm{Al}_{2} \mathrm{O}_{3}$ & 3,4 \\
\hline $\mathrm{Fe}_{2} \mathrm{O}_{3}$ & 3,8 \\
\hline $\mathrm{Na}_{2} \mathrm{O}$ & 1,4 \\
\hline $\mathrm{K}_{2} \mathrm{O}$ & 0,4 \\
\hline $\mathrm{MgO}$ & 1,4 \\
\hline $\mathrm{SO}$ & 0,2 \\
\hline $\mathrm{F}$ & 0,3 \\
\hline$П$ рочее & 4,5 \\
\hline
\end{tabular}

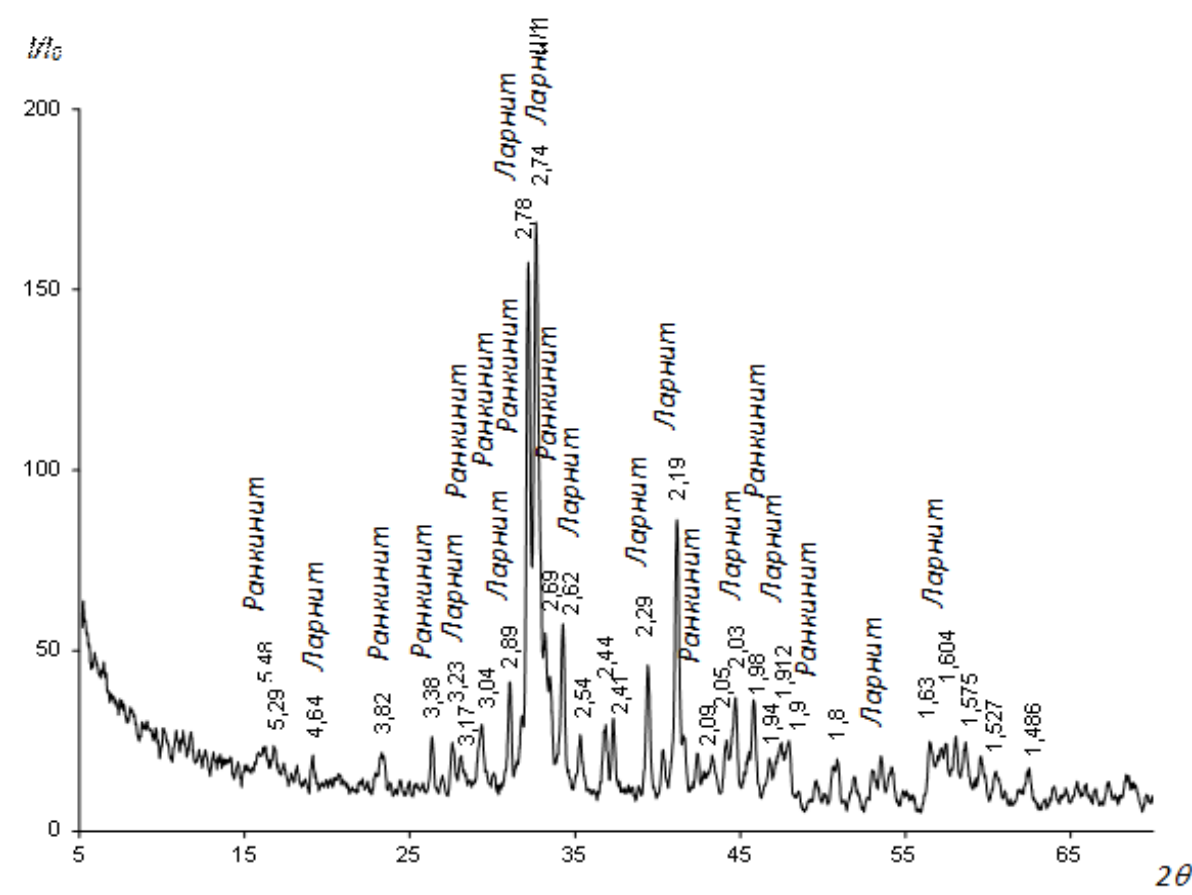

Рис. 1. Фрагмент дифрактограммы свежего нефелинового шлама с указанием фазовой принадлежности основных пиков 
Важную роль при подборе компонентов вяжущих играет изучение гранулометрического состава, который показывает относительное содержание в них частиц с различными размерами. Гранулометрический состав нефелинового шлама представлен в табл. 2.

Нефелиновый шлам является нетоксичным отходом и отнесен к 5-му классу опасности (неопасные отходы) для окружающей природной среды, что подтверждает заключение аккредитованной лаборатории АНО «Экспертно-аналитический центр по проблемам окружающей среды «ЭКОТЕРРА», г. Москва. Удельная активность естественных радионуклидов, содержащихся в нефелиновом шламе, не превышает гигиенический норматив, установленный для отходов промышленного производства, используемых при изготовлении строительных материалов 1-го класса и, соответственно, равна 66,9 Бк/кг при нормативе 370 Бк/кг [9].

В качестве другого возможного вяжущего компонента дорожных смесей нами был рассмотрен и исследован гипсоангидритовый отход (ГАО) производства фтористого алюминия ОАО «РУСАЛ Ачинск». Проведенными исследованиями установлено, что на образцах гипсоангидритовых отходов отмечены в основном характерные линии гипса ( $\mathrm{CaSO}_{4} \times 2 \mathrm{H}_{2} \mathrm{O}$, JCPDS, 36$432)$ и бассанита $\left(\mathrm{CaSO}_{4} \times 0,5 \mathrm{H}_{2} \mathrm{O}, \mathrm{JCPDS}, 41-224\right)$, присутствуют также линии кальцита $\left(\mathrm{CaCO}_{3}\right.$, $d=3,86 ; 3,03 ; 1,912 \AA, J C P D S, 47-1743)$. Это подтверждается данными фазового состава этих отходов, которые на 90-95 \% состоят из сульфата кальция, представленного смесью ангидрита и гипса (табл. 3).

Данный отход размещен на гипсохранилище ОАО «РУСАЛ Ачинск» в количестве более 120 тыс. т и в настоящее время практически не используется. Ранее данный отход вовлекался во вторичную переработку в ограниченных объемах, необходимых для производства содопродуктов ОАО «РУСАЛ Ачинск» [10]. Вместе с тем по своим физико-химическим свойствам данный гипсоангидритовый продукт может быть использован в качестве компонента комплексного вяжущего для дорожно-строительных смесей.

Таблица 2. Гранулометрический состав нефелинового шлама

\begin{tabular}{|l|c|c|c|c|c|c|c|c|}
\hline $\begin{array}{l}\text { Размер } \\
\text { фракции, мм }\end{array}$ & менее 0,01 & $0,01-0,05$ & $0,05-0,1$ & $0,1-0,25$ & $0,25-0,5$ & $0,5-1,0$ & $1,0-2,0$ & более 2,0 \\
\hline $\begin{array}{l}\text { Содержание } \\
\text { фракции, \% }\end{array}$ & 1,2 & 5,7 & 8,1 & 20 & 26 & 26,6 & 11,1 & 1,3 \\
\hline
\end{tabular}

Таблица 3. Фазовый состав гипсосодержащих отходов ОАО РУСАЛ Ачинск»

\begin{tabular}{|c|c|}
\hline Компонент & Содержание, \% \\
\hline $\mathrm{CaSO}_{4} \times 2 \mathrm{H}_{2} \mathrm{O}$ & 36,6 \\
\hline $\mathrm{CaSO}_{4} \times 0,5 \mathrm{H}_{2} \mathrm{O}$ & 5,4 \\
\hline $\mathrm{CaSO}_{4}$ & 54,0 \\
\hline $\mathrm{CaF}_{2}$ & 2,4 \\
\hline$\left(\mathrm{Na}_{2} \mathrm{O} \times \mathrm{K}_{2} \mathrm{O}\right) \times \mathrm{Al}_{2} \mathrm{O}_{3}$ & 0,6 \\
\hline Прочие соединения & 1,0 \\
\hline
\end{tabular}


Для разработки оптимальных рецептур комплексного вяжущего компонента дорожных смесей на основе гипсоангидритовых отходов и нефелинового шлама ОАО «РУСАЛ Ачинск» были проведены исследования по изучению характеристик и подбору составов с добавками различных количеств данных отходов и выявлению пределов прочности образцов по контрольным срокам твердения. В связи с длительным хранением гпсоангидритовых отходов на гипсохранилище для активации его поверхности он предварительно измельчался. Тонкость помола соответствовала 55-56 \% доли материала, измельченного до класса 0,08 мм. Активацию проводили в лабораторной шаровой мельнице МЛБ в периодическом режиме. Мелющие тела - сталь диаметром 1-3 см. Шаровая загрузка 40 кг. Загрузка материала 50 кг. Длительность измельчения составляла 30 мин. Нефелиновый шлам, который использовали во влажном состоянии, отбирали со шламохранилища ОАО «РУСАЛ Ачинск».

Для приготовления дорожной смеси применяли щебеночную смесь фракции 0-40 мм, которую смешивали с нефелиновым шламом с добавлением гипсоангидритовых отходов. По данным РФА, щебень представлен в основном кальцитом $\left(\mathrm{CaCO}_{3}, d=3,86 ; 3,03 ; 1,912 \AA\right.$, JCPDS, 47-1743). В подчиненных количествах (до $10 \%$ от основной фазы) присутствуют кварц $\left(\mathrm{SiO}_{2}\right.$, $d=4,26 ; 3,34 ; 1,818 \AA$, JCPDS, 5-490), доломит $\left(\mathrm{CaMg}\left(\mathrm{CO}_{3}\right)_{2}, d=2,89 ; 2,20 ; 2,01 \AA\right.$, JCPDS, 36-426) и каолин $\left(\mathrm{Al}_{2} \mathrm{Si}_{2} \mathrm{O}_{5}(\mathrm{OH})_{4}, d=7,19 ; 3,59 ; 1,47 \AA, J C P D S, 6-201\right)$. Возможно наличие небольших количеств клинохлора $\left((\mathrm{Mg}, \mathrm{Al})_{6}(\mathrm{Si}, \mathrm{Al})_{4} \mathrm{O}_{10}(\mathrm{OH})_{8}, \mathrm{JCPDS}, 16-351\right)$ и гриналита $\left(\mathrm{Fe}_{3}\left(\mathrm{Si}_{2} \mathrm{O}_{5}\right)(\mathrm{OH})_{4}, J C P D S\right.$, 39-337).

При уплотнении во влажном состоянии нефелиновый шлам текущего производства и щебеночно-песчаная смесь обладают способностью преобразовываться в монолитный водостойкий материал для дальнейшего набора прочности во времени. Исследование прочностных свойств образцов, приготовленных из данных смесей, показало, что при использовании в качестве активатора нефелинового шлама измельченных гипсоангидритовых отходов в диапазоне от 5 до 30 \% масс. прочность образцов по сравнению с применением одного нефелинового шлама возрастает в 1,8-2,2 раза. Следует отметить, что даже при минимальных 3-5\%ных дозировках гипсоангидритовых отходов в смесь с нефелиновым шламом обеспечивается высокая прочность образцов по срокам твердения: соответственно для 7 сут - 6,1 МПа, 14 сут - 9,8 МПа, 28 сут твердения - 10,7 МПа (рис. 2). При введении добавки гипсоангидрита в исследуемые образцы из гипсо-нефелино-известняковой смеси отмечено, что прочность образцов при сжатии возрастает значительно существеннее, чем прочность образцов на растяжение при изгибе.

Так, при добавке 5 \% гипсоангидритовых отходов при 28-суточной выдержке образцов предел прочности при изгибе составил 6,2 МПа, а при 30\%-ной добавке гипсоангидритовых отходов соответственно 9,1 МПа, в то время как контрольные образцы нефелиново-щебеночной смеси без добавок гипсоангидрита имели прочность при изгибе 4,1 МПа.

Скорость набора прочности в ранние сроки обусловлена взаимодействием сульфата кальция с гидратирующимися двухкальциевым силикатом и кальций-магниевым силикатом. Характер динамики набора прочности (рис. 2) соответствует механизму гидратационного твердения нефелиново-щебеночной смеси с добавкой гипсоангидритовых отходов. При малых добавках гипсоангидритовых отходов в состав комплексного нефелинового вяжущего сульфат кальция практически полностью связывается остатками соды в неотмытом ларните и алюмосиликата- 
ми с формированием гидросульфоалюминатов кальция. При этом сульфат-ион при избытке кальцита быстро замещается карбонатом. По данным РФА, образец представлен в основном частично гидратированным ларнитом $\left(\beta-\mathrm{Ca}_{2} \mathrm{SiO}_{4}, d=2,78 ; 2,74 ; 2,19 \AA, J C P D S, 29-371\right)$ (рис. 3). В подчиненных количествах присутствует трехкальциевый силикат ранкинит $\left(\mathrm{Ca}_{3} \mathrm{Si}_{2} \mathrm{O}_{7}, d=3,82\right.$; 3,$17 ; 3,04 \AA$, JCPDS, 23-124). Прослеживаются следы термонатрита $\left(\mathrm{Na}_{2} \mathrm{CO}_{3} \cdot 2 \mathrm{H}_{2} \mathrm{O}, d=5,29 ; 4,64\right.$; $2,21 \AA, J C P D S, 2-878)$ и гипса $\left(\mathrm{CaSO}_{4} \cdot 2 \mathrm{H}_{2} \mathrm{O}, d=7,59 ; 4,28 ; 3,79 \AA, J C P D S, 36-432\right)$. Отчетливо проявляются линии новообразованной фазы - канкринита $\left(\left(\mathrm{Na}_{6} \mathrm{Ca}_{2} \mathrm{Al}_{6} \mathrm{Si}_{6} \mathrm{O}_{24}\left(\mathrm{CO}_{3}\right)_{2} \cdot 2 \mathrm{H}_{2} \mathrm{O}, d=5,48\right.\right.$; 4,13; 3,23 $\AA, J C P D S, 46-1332)$.

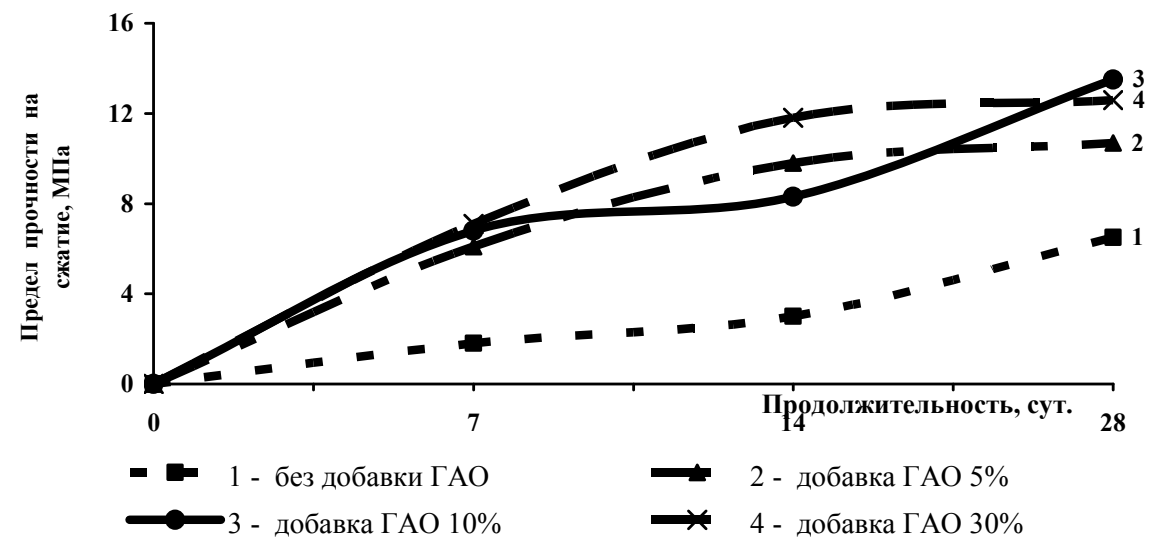

Рис. 2. Кинетика твердения образцов нефелиново-известняковой смеси в зависимости от добавок гипсоангидритовых отходов (ГАО)

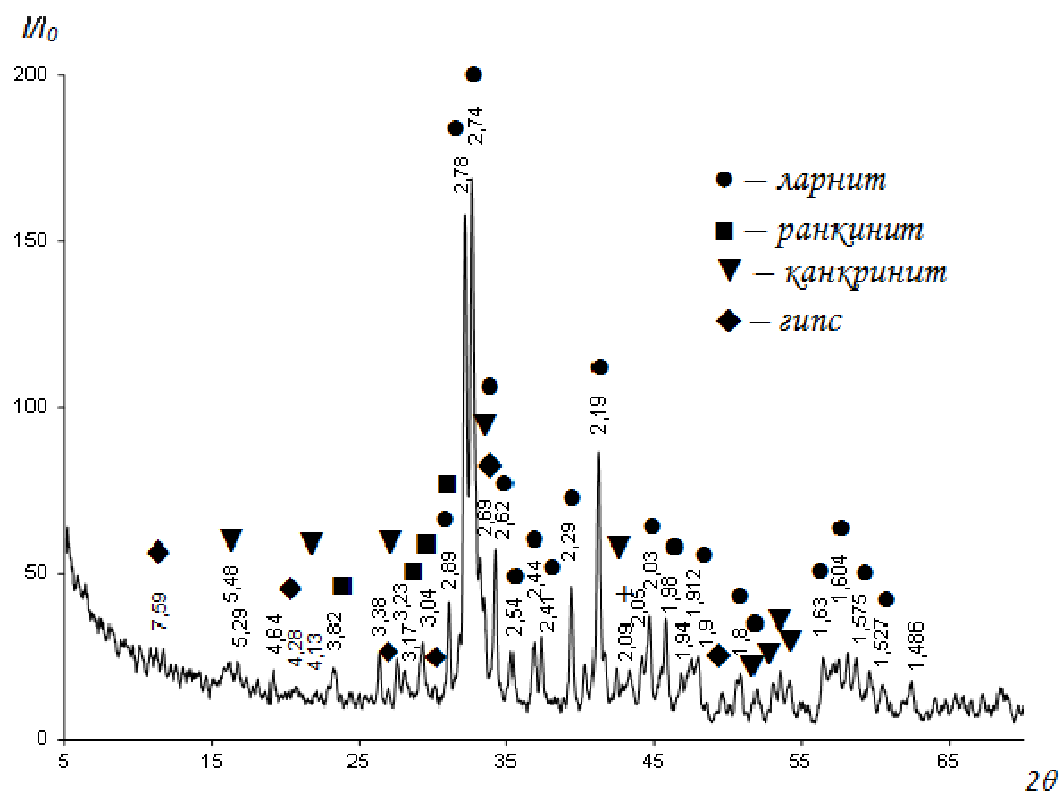

Рис. 3. Фрагмент дифрактограммы нефелинового шлама с добавками гипсоангидрита с указанием фазовой принадлежности основных пиков 
Проведенные электронно-микроскопические исследования показали, что нефелиновый шлам представлен в основном пористыми частицами ларнита (300-500 мкм) (рис. 4a). В порах отмечено присутствие остатков соды.

На микрофотографиях нефелинового шлама с измельченным известняком видно, что внутри частиц шлама имеются крупные полости (до 50-100 мкм), пустые или проросшие пластинчатыми кристаллами кальцита (рис. 4б).

На микрофотографиях аншлифа комплексного нефелинового вяжущего с добавками гипсоангидритовых отходов хорошо заметно формирование тонких пластинок новой фазы (канкринита) в порах и по поверхности ларнита, а также тонких корочек по поверхности кальцита (рис. 5). При больших дозировках ГАО (до 30 \% масс.) гипс обволакивает поверхность частиц щебня и ларнита и связывание матрицы обусловлено образованием более слабых мостиковых гипсовых связей. При этом процесс гидратации силиката кальция становится замедленным, а кинетика вялотекущей из-за замены мостиковых алюмосиликатных гидратационных связей на гипсовые и соответствующего их ослабления приводит к некоторому снижению прочности образцов. Химические превращения действия гипсоангидритовых отходов в составе комплексного нефелинового вяжущего на первой стадии можно представить взаимодействием сульфата кальция с содержащимися в шламе гидроалюминатом кальция по следующей схеме:

$$
3 \mathrm{CaO} \cdot \mathrm{Al}_{2} \mathrm{O}_{3} \cdot 6 \mathrm{H}_{2} \mathrm{O}+3\left(\mathrm{CaSO}_{4} \cdot 2 \mathrm{H}_{2} \mathrm{O}\right)+19 \mathrm{H}_{2} \mathrm{O}=3 \mathrm{CaO} \cdot \mathrm{Al}_{2} \mathrm{O}_{3} \cdot 3 \mathrm{CaSO}_{4} \cdot 31 \mathrm{H}_{2} \mathrm{O}
$$

Образующийся в результате этой реакции высокосульфатный гидросульфоалюминат кальция увеличивает объем гидратной фазы и ускоряет процесс гидратации нефелинового шлама. При избытке кальцита сульфат-ион быстро замещается карбонатом. По данным РФА, в образцах нефелиново-щебеночной смеси с добавкой гипсоангидритовых отходов после 14-суточной выдержки отмечены канкринит $\left(\mathrm{Na}_{6} \mathrm{Ca}_{2} \mathrm{Al}_{6} \mathrm{Si}_{6} \mathrm{O}_{24}\left(\mathrm{CO}_{3}\right)_{2} \cdot 2 \mathrm{H}_{2} \mathrm{O}\right.$ и ранкинит $\left(\mathrm{Ca}_{3} \mathrm{Si}_{2} \mathrm{O}_{7}\right)$, также в небольших количествах присутствует этрингит $-\mathrm{Ca}_{6} \mathrm{Al}_{2}\left(\mathrm{SO}_{4}\right)_{3} \cdot(\mathrm{OH})_{12} \cdot 26 \mathrm{H}_{2} \mathrm{O}$. Последующее твер-
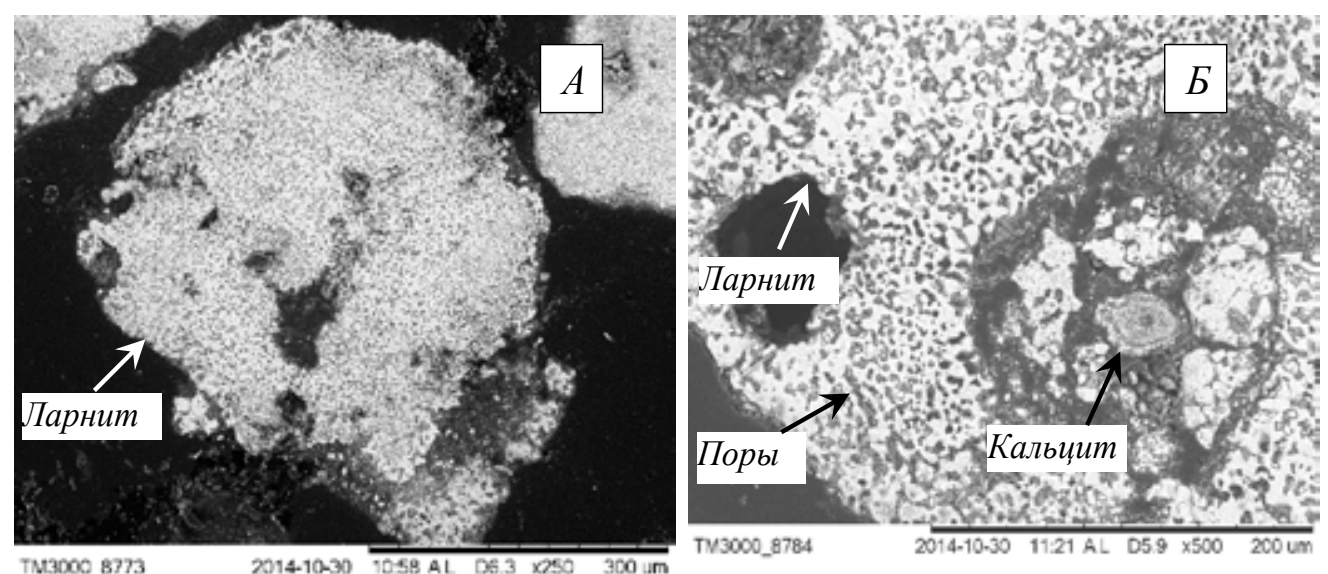

Рис. 4. Микроструктура частиц свежего нефелинового шлама (аншлиф, эпоксидная смола). А - нефелиновый шлам; Б - нефелиновый шлам с измельченным известняком; увеличение: $\mathrm{A}-\times 250$; Б $-\times 500$ 

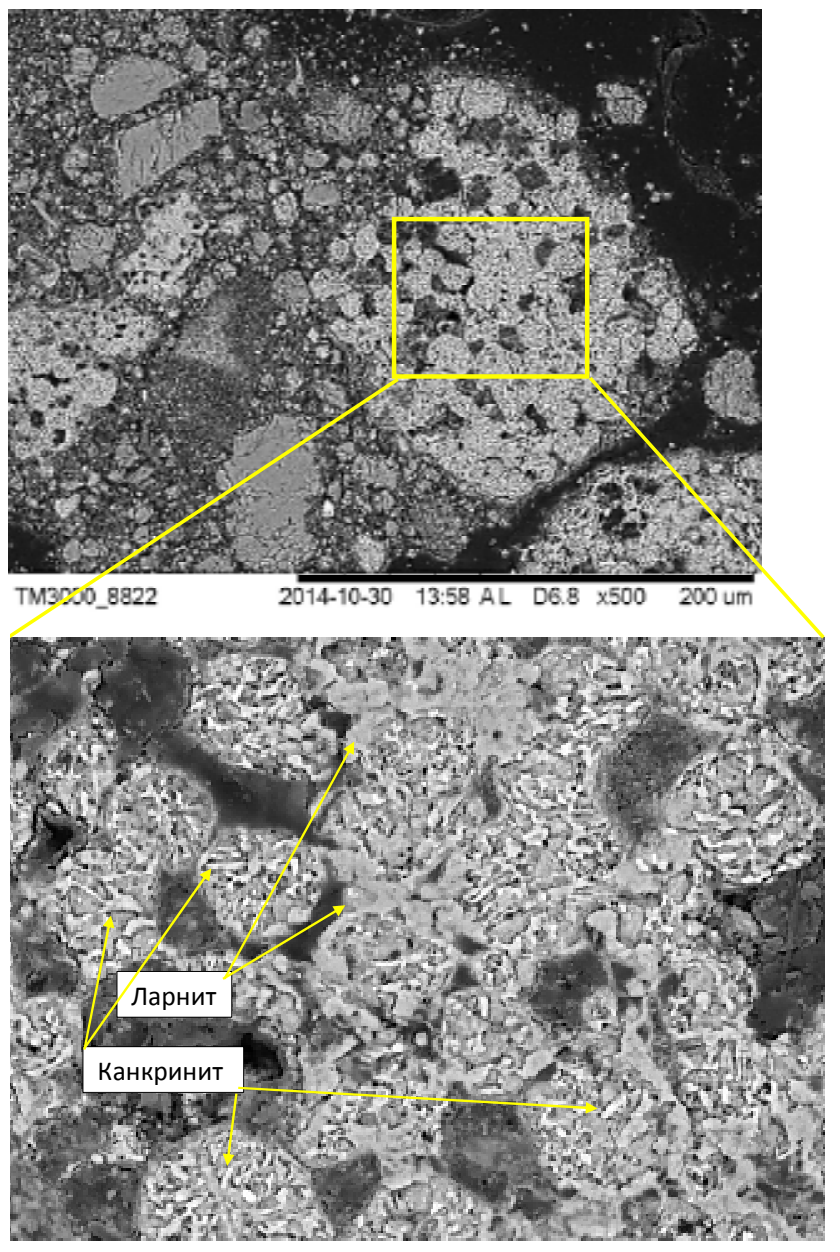

Рис. 5. Микроструктура частиц комплексного нефелинового вяжущего с добавками гипсоангидритовых отходов (5 \% ГАО, 14 сут); увеличение: основной кадр $-\times 500$; увеличенный фрагмент $-\times 1500$

дение нефелинового шлама в гипсо-нефелино-известняковой смеси обеспечивается в основном за счет гидратации двухкальциевого силиката, содержащегося в шламе, с образованием различных форм гидросиликатов кальция: $2 \mathrm{CaO} \cdot \mathrm{SiO}_{2} \cdot \mathrm{H}_{2} \mathrm{O}, \mathrm{CaO} \cdot \mathrm{SiO}_{2} \cdot \mathrm{H}_{2} \mathrm{O}, 2 \mathrm{CaO} \cdot \mathrm{SiO}_{2} \cdot 2 \mathrm{H}_{2} \mathrm{O}$, $3 \mathrm{CaO} \cdot \mathrm{SiO}_{2} \cdot \mathrm{H}_{2} \mathrm{O}$.

На основе полученных данных по рецептурам комплексного вяжущего и с учетом опыта приготовления дорожного покрытия с применением отходов производства была разработана технология строительства дорожных одежд с использованием комплексного вяжущего на основе нефелинового шлама и гипсосодержащего компонента. Для приготовления дорожной смеси основания автодороги использовали $65 \%$ масс. щебеночной смеси фр. 0-40 мм, в которую добавляли 30 \% масс. нефелинового шлама с дополнительным вводом 5 \% масс. гипсосодержащего компонента (гипсоангидритовых отходов ОАО «РУСАЛ Ачинск»).

Приготовление дорожной смеси осуществляли на промплощадке ООО «ДПМК Ачинская» путем тщательного перемешивания компонентов. Промышленные испытания по разработанной технологии проводили в летне-осенний период 2012 г. на выбранных опытных

$$
-1078-
$$


участках реконструируемой автодороги Красноярск-Железногорск. Приготовленную дорожную смесь транспортировали на опытные участки автодороги и производили укладку основания механизированным способом. По данным лабораторных исследований образцов дорожных смесей применение комплексного гипсонефелинового вяжущего технологически более эффективно с использованием измельченных гипсоангидритовых отходов, так как обеспечивается активация его поверхности и активность нефелинового шлама увеличивается при введении в его состав не менее 5 \% масс. измельченной гипсосодержащей добавки, которая выполняет роль активатора твердения и увеличивает прочностные свойства дорожных смесей на основе нефелинового шлама $[5,9]$.

Одним из необходимых свойств дорожных смесей, особенно в Сибири, является ее морозостойкость. В качестве минеральной добавки, повышающей морозостойкость, в составе гипсо-нефелиново-известняковой смеси были исследованы пыли газоочистных сооружений печей спекания ОАО «РУСАЛ Ачинск». Учитывая, что химический состав пыли по полям электрофильтров печи спекания различный, для исследований были отобраны пробы пыли от каждого поля электрофильтра в отдельности. Как показал химический анализ состава пыли электрофильтров, распределение компонентов по полям электрофильтров разное. Наибольшая массовая доля хлоридов и соединений серы отмечается в пыли, отобранной с 4-го и 5-го полей электрофильтра, которая соответственно равна 22,5 и 27,6 \% масс., в то время как пыль 1-3-го полей электрофильтра печи спекания имела массовые доли этих соединений от 1,3 до 3,5 \% масс. Поэтому для состава, увеличивающего морозостойкость, целесообразно рассматривать только пыль 4-го и 5-го полей электрофильтров печей спекания ОАО «РУСАЛ Ачинск», так как содержание хлоридов и оксидов серы в 1-3-м полях недостаточно и не обеспечивает снижения температуры замерзания поровых растворов при принятой дозировке, необходимой для достижения высоких показателей по морозостойкости образцов. По данным РФА, пыль 4-го и 5-го полей электрофильтра представлена примерно равными количествами галита ( $\mathrm{NaCl}, d=3,26 ; 2,83 ; 1,997 \AA$, JCPDS, 5-628), сильвинита $(\mathrm{KCl}, d=3,66 ; 3,15 ; 2,22$ $\AA ⿻ 上 丨 P S, 41-1476)$ и кальцита $\left(\mathrm{CaCO}_{3}, d=3,86 ; 3,03 ; 1,877 \AA\right.$, JCPDS, 47-1743) (рис. 6). До $50 \%$ от основных фаз составляет афтиталит $\left(\mathrm{K}_{3} \mathrm{Na}\left(\mathrm{SO}_{4}\right)_{2}, d=4,09 ; 2,94 ; 2,04 \AA\right.$, JCPDS, 20-928). Возможно наличие небольших количеств арканита $\left(K_{2} S_{4}, d=2,94 ; 2,45 ; 2,34 \AA\right.$, JCPDS, 44-1414). На микрофотографии частиц пыли электрофильтров отмечен кальцит, который представлен неровными обломочными частицами (30-50 мкм). Прослеживаются массивные (до 100 мкм) частицы галита, вмещающие мелкие (1-10 мкм) кубики сильвинита. Присутствуют таблитчатые вытянутые по оси кристаллы афтиталита (3-5×10-20 мкм). Кроме того, галит имеется в виде мелкой пыли субмикронных размеров.

Хлориды в гипсонефелиновом вяжущем оказывают положительное влияние на морозостойкость дорожной смеси.

Так, при использовании состава вяжущего на основе одного нефелинового шлама морозостойкость образцов имела 62 цикла, в то время как применение состава вяжущего с добавками гипсоангидритовых отходов и пыли электрофильтров печей спекания приводило к увеличению морозостойкости до 88-92 циклов (рис. 7).

Добавка пыли 4-5-го полей электрофильтров менее 0,5 \% масс. снижала морозостойкость испытываемых образцов до 75 циклов. Добавка пыли 4-5-го полей электрофильтров 


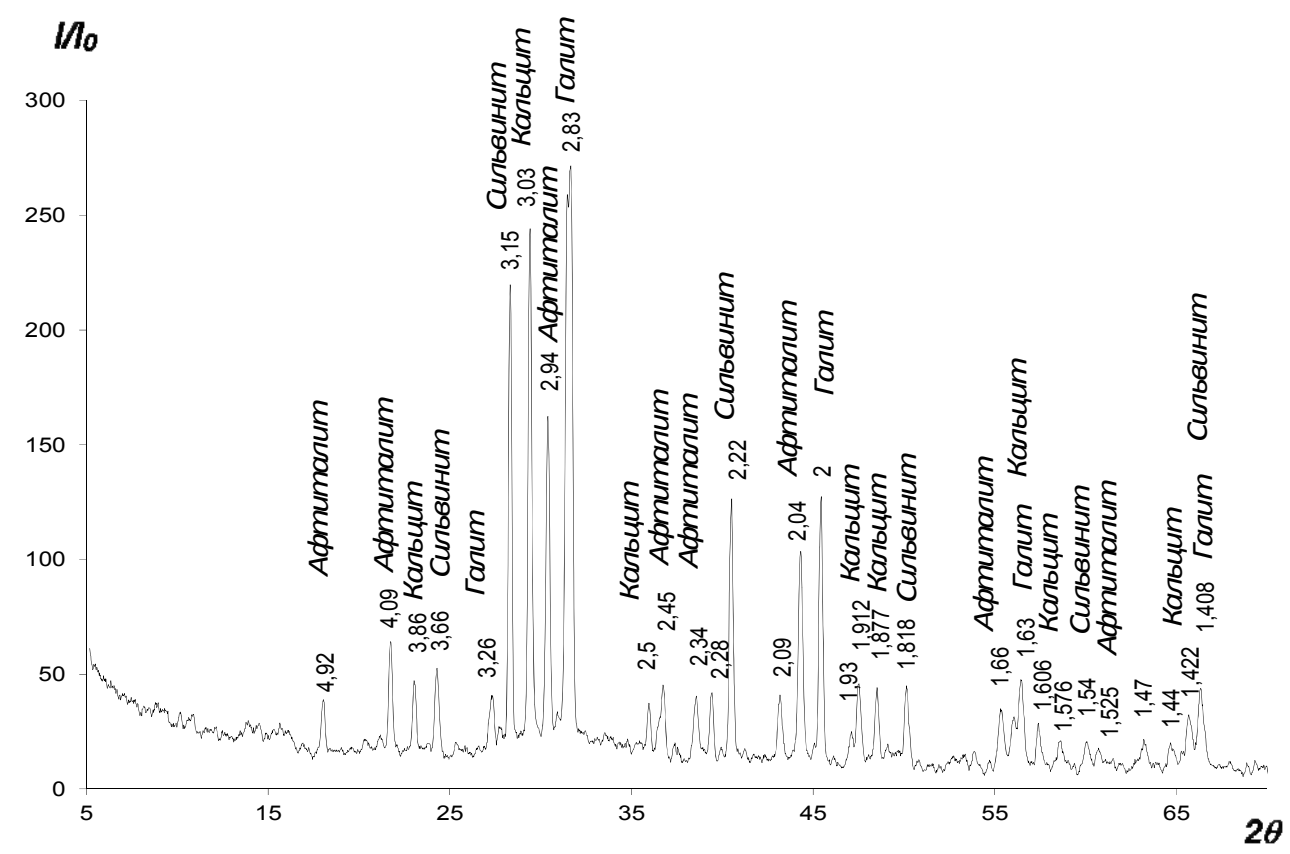

Рис. 6. Фрагмент дифрактограммы пыли электрофильтров печи спекания с указанием фазовой принадлежности основных пиков

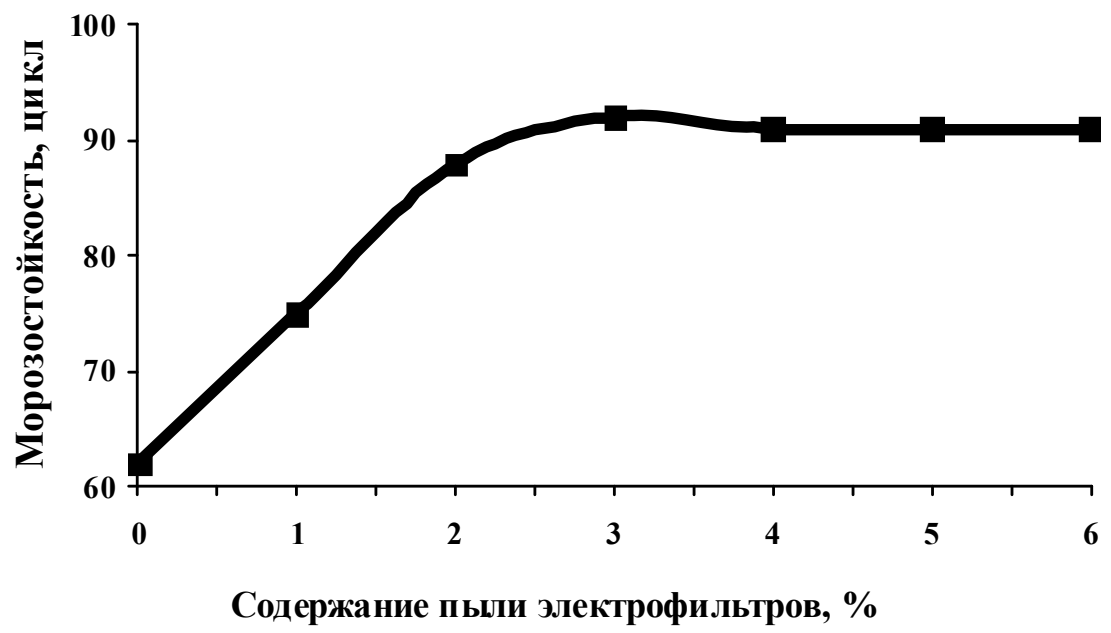

Рис. 7. Изменение морозостойкости образцов дорожных смесей в зависимости от добавок пыли электрофильтров печи спекания

более 5 \% в состав вяжущего не снижала морозостойкость, но приводила к ухудшению динамики набора прочности вследствие гидратации вяжущего образующимся солевым раствором. Добавка пыли, взятой с 1-3-го полей электрофильтра печей спекания, не обеспечивала значительного повышения морозостойкости образцов при принятой дозировке и находилась 
на уровне 65 циклов. Химические соединения, входящие в состав пылей электрофильтров печей спекания, способствуют повышению удобообрабатываемости (однородности) и удобоукладываемости (плотности) гидроизоляционных свойств дорожного покрытия и повышают его морозостойкость. Подтверждением этого служит тот факт, что нефелиновый шлам с добавкой гипсоангидритовых отходов и пылей 4-5-го полей электрофильтров печей спекания имеет большую стабильность при перепадах температур, с одной стороны, за счет гибких связей адсорбционного типа, образующихся благодаря высокой дисперсности гипсоангидритовых отходов и пыли электрофильтров, а с другой - из-за развития смешанной коагуляционно-кристаллической структуры в связи с присутствием в шламе щелочных соединений.

\section{Заключение}

На основании проведенных исследований и результатов опытно-промышленных испытаний на опытных участках автодороги можно сделать следующие выводы:

- с точки зрения улучшения технико-технологических показателей при использовании нефелинового шлама с добавкой в качестве активатора гипсоангидритовых отходов обеспечивается сокращение времени набора прочности образцов и увеличение срока службы дорожного полотна за счет способности его повышать прочность уплотненного слоя в процессе эксплуатации дороги;

- ввод в гипсонефелиновое вяжущее пыли газоочистных сооружений печей спекания ОАО «РУСАЛ Ачинск» позволяет применяемые активаторы и различные добавки заменить на отходы промышленного производства и получить при этом новые технологические эффекты, обеспечивающие более высокие морозостойкость и улучшенные эксплуатационные свойства дорожного покрытия;

- применение предлагаемого комплексного гипсонефелинового вяжущего при укреплении основания дорог сможет в процессе эксплуатации повысить трещиноустойчивость и снизить колейность дорожного полотна.

\section{Список литературы}

[1] Обзорная информачия о передовых отечественных и зарубежных технологиях $u$ дорожно-строительных материалах. М., Росавтодор, 2005, 95 с. [Overview of domestic and foreign advanced technology and road-building materials, Moscow, Rosavtodor, 2005. 95 p.]

[2] Чумаков В.И., Чумаков И.В., Кирсанова А.А. Вестник ЮУрГУ. Сер. Металлургия, 2013, 13(1), 56-60 [Chumakov V.I., Chumakov I.V., Kirsanova A.A. Bulletin of the South Ural State University. Ser. 'Metallurgy', 2013, 13(1), 56-60]

[3] Снуриков А.П. Комплексное использование сырья в иветной металлургии. М.: Металлургия, 1986, с. 120-125 [Snurikov A.P. Integrated use of raw materials in the non-ferrous metallurgy. Moscow, Metallurgy, 1986, 120-125 (in Russian)

[4] Wilson A.D., Nicholson J.W. Acid-base cements. Their biomedical and industrial applications, Cambridge University Press, 1993, 418 p.

[5] Бескровный В.М. Дис. ... канд. техн. наук. Омск, 1983. 122 с. [Beskrovnyi V.M. Dissertation of candidate of technical sciences, Omsk, 1983, 122 p.]

$$
-1081-
$$


[6] Головных Н.В., Бычинский В.А., Шепелев И.И. и др. Известия ВУЗов. Цветная металлургия, 2010, 3, 23-28 [Golovnykh N.V., Bychinsky V.A., Shepelev I.I. et. al. Proceedings of the universities. Non-ferrous metallurgy, 2010, 3, 23-28]

[7] Golovnykh N.V., Bychinsky V.A., Tupitsin A.A. et al. Russian Journal of Non-Ferrous Metals, 2010, 51(3), 222-226.

[8] Шепелев И.И., Бочков Н.Н., Сахачев А.Ю., Головных Н.В. Metal Russia, 2014, 11, 60-63 [Shepelev I.I., Bochkov N.N., Sakhachev A.Iu., Golovnykh N.V. Metal Russia, 2014, 11, 60-63]

[9] Шепелев И.И., Бочков Н.Н., Дашкевич Р.Я., Сахачев А.Ю. Научные основы и практика переработки руд и техногенного сырья: докл. XIX Междунар. НТК. Екатеринбург: УГГУ, 2014, c. 244-248 [Shepelev I.I., Bochkov N.N., Dashkevich R.Ia., Sakhachev A.Iu. Scientific bases and practice of processing of ore and technogenic raw materials. XIX International Conference, Ekaterinburg, EGGU, 2014, 244-248]

[10] Головных Н.В., Шепелев И.И., Бычинский В.А. и др. Известия вузов. Химия и химическая технология, 2011, 4, 43-51 [Golovnykh N.V., Shepelev I.I., Bychinsky V.A. et. al. Izvestiia vuzov. Khimia i khimicheskaia tekhnologiia [Proceedings of the universities. Chemistry and Chemical Technology], 2011, 4, 43-51] 